\title{
An Investigation on the Adoption of Rainwater Harvesting Based on the Theory of Planned Behaviour and Norm Activation Model
}

Nagarajan Shanmugavel ( $\sim$ nagarajanps@alagappauniversity.ac.in )

Alagappa University https://orcid.org/0000-0001-5263-111X

Rema Rajendran

Noorul Islam University: Noorul Islam Centre For Higher Education

\section{Research Article}

Keywords: Rainwater harvesting, Theory of Planned Behaviour, Norm Activation Model, personal norm, subjective norm, environmental responsibility, environmental concern

Posted Date: March 8th, 2022

DOI: https://doi.org/10.21203/rs.3.rs-864219/v1

License: (c) (i) This work is licensed under a Creative Commons Attribution 4.0 International License.

Read Full License 


\section{Abstract}

The notion of the study is to reflect the concepts and benefits of rainwater harvesting to the households to recharge ground water that manifests sustainable ground water. Hence to study the adoption of rainwater harvesting the Theory of Planned Behaviour and Norm Activation Model has been synergized. The constructs such as personal norm, subjective norm, intention to acquire rainwater harvesting knowledge, environmental responsibility and environmental concern have been used to explain the adoption of rainwater harvesting. A sample size consisting of 400 participants constructing and likely to construct houses have been had taken for the study. Structural Equation Modelling was used to analyze the data, inter alia moderation and mediation analysis was also done. The study results typically show that all the factors show significant relationship with adoption of rainwater harvesting, similarly intention to acquire rainwater harvesting knowledge moderates the relationship exists between environmental concern; environmental responsibility and rainwater harvesting. Based on the results, significant theoretical and social implications have been made.

\section{Introduction}

Groundwater is available almost everywhere beneath the land surface and is a chief source of water to domestic, industrial and agricultural use, though nonrenewable (Alley et al., 1999) it plays a significant role to the nations' economic and social development (Pophare et al., 2014). However, the increase in population as urges in enabling farming, infrastructure and industries mandates the individuals and institutions to use more water and results in the exploitation and depletion of groundwater resources. The adverse effect attributed by the scarcity of ground water would be very severe, hence traditionally Indians had the practice of water harvesting, however in the current context because of its decline (Kumar et al., 2006) the respective Governments through ordinance mandated the establishment of rainwater harvesting system to residential, commercial and industrial buildings (Centre for Science and Environment). Nevertheless, most of the individuals show less interest, that consequently lacks periodical maintenance and radically requires thorough understanding and needs increase in responsibility and high concern towards sustainable groundwater. As rainwater harvesting $(\mathrm{RWH})$ increases the ground water quality and level (Glendenning \& Vervoort, 2010), researchers have urged to adopt serious strategies to alleviate substantial exploitation of groundwater (Pophare et al., 2014). Similarly, very less researches were carried out as how and why individuals establish rainwater harvesting system in their respective premises. It is felt by the researcher that if individuals have a concern towards environment and feel responsible for the depletion of groundwater resources certainly no nation would face water crisis. Based on this premise the current research employs the Theory of Planned Behaviour (TPB) and Norm Activation Model (NAM) with the addition of constructs like intention to acquire knowledge to investigate the adoption of rainwater harvesting system.

The Theory of Planned Behaviour propounded by Ajzen (1991) remained as a prominent and pioneer model to predict individuals' intentions. In its inception TPB was used to predict health related behaviours (Godin \& Kok, 1996; Sheeran \& Taylor, 1999), however because of its significant predicting power (Conner 
\& Armitage, 1998; Conner et al., 2003) it has been extensively used in social science studies, subsequently serves as an imperative tool to predict and promote pro-environmental behavioral intentions (Masud et al., 2016). Similarly, the Norm Activation Model propounded by Schwartz's (1977) as intends to understand how the pro-environmental behaviors are nurtured, is adopted to explain the adoption of RWH. At the same time certain constructs away from TPB have been inherited from prior studies based on the concrete notion that; subjective norms (SN) significantly influenced behavioral decisions in the adoption of energy-efficient lighting (Lee et al., 2013), personal norm (PN) inherited from NAM, on the purchase of pro-environmental products (Kim \& Seock, 2019), intention to acquire knowledge on comprehension of knowledge and knowledge transfer (Pérez-Nordtvedt et al., 2008), environmental responsibility (ER) derived from NAM (Yue et al., 2020), on sustainable consumption (Barr et al., 2011), environmental concern (EC) on individual behavioural change (Wong \& Wan, 2011). Whereby, constellation of constructs drawn from prior studies though explained different outcomes the current study intends to define the adoption of rainwater harvesting in India. Moreover, based on the extensive reviews, no studies have explored these constructs to explain the behaviour of individuals towards the adoption of rainwater harvesting (ARWH). In the meantime, substantial investment has been made in India on rainwater harvesting purported to befit the needs of the society in alleviating water scarcity (Kumar et al., 2006) and to promote sustainable groundwater. Similarly, Pandey et al. (2003) suggested to undertake research purported to investigate the reasons behind the shrouded interest towards RWH. However, due to the ignorance and withering responsibility of the individuals towards the seriousness of the imminent adverse effect of exploitation of groundwater and usefulness of rainwater harvesting people inadvertently implement rainwater harvesting systems in their respective premises which further leads to rebound effect.

Several researchers have suggested the significance of RWH to human society and environment. Amongst, Pandey et al. (2003) signified the RWH system as an adaptation to climate change, improving irrigation (Boers \& Ben-Asher, 1982), collectively indoor use, food production and groundwater recharge (Stout et al., 2017), similarly several other researchers have studied RWH in line with the aforesaid approaches. Hence, to provide a worthy and realistic perspective to understand and explain the gaps between the less intention towards rainwater harvesting and behaviour of Indians, this research expanded with the constructs like personal norm, intention to acquire rainwater harvesting knowledge, environmental responsibility and environmental concern.

\section{Theoretical Basis And Hypotheses \\ 2.1. Rainwater Harvesting (RWH)}

In contemplation with the maladies like egregious water scarcity, excessive floods and jarring water pollution, rainwater harvesting has become an unparalleled panacea which is imperative for the growing population. Rainwater harvesting is the method of collecting and storing rainwater for various purposes (Boers \& Ben-Asher, 1982). Being India a tropical monsoon country its potential to harvest rains is irresistibly possible, despite the growing awareness of need for rainwater harvesting (Kumar et al., 2006), 
there is low adoption of rainwater harvesting in India. This study assumes the low adoption of RWH is because of the shrouded environmental responsibility and concern. Hence, to comprehensively explore the original reasons for the low adoption of rainwater harvesting this empirical study adopts personal norm from Norm Activation Model, intention to acquire rainwater harvesting knowledge (IARWH), environmental responsibility, environmental concern along with the subjective norms of the Theory of Planned Behaviour.

\subsection{Personal norms (PN)}

Moral obligations play a significant role on the moral intentions when individuals are confronted with handling situations which conflicts self and public interests (Lam, 1999). Personal norms or moral norms are connoted as the humanistic values, manifests as obligations and compassion that are imbued within oneself and gets transpired when encountered with social tribulations. Accordingly, Schwartz (1977) defined personal norms as the internalized core values that are presumed as moral obligations and plays a key role in decision making. Researchers like Lindenberg \& Steg (2007) argued that individuals are steered to elicit pro-environmental behaviors based on the inner motivation as guided by the conscience or morality. Further, Schwartz (1977) affirmed that personal norms do play a poignant role in performing altruistic behaviour. The value system, predicting ability of the repercussions of events and the preparedness to bear the responsibility influence the personal norms of individuals (Stern, 2000). Similarly, other empirical studies also have affirmed the influence of personal norms on proenvironmental behaviours and actions (Stern \& Dietz, 1994; Mehmetoglu, 2010).

In the meantime, several researchers have addressed the active engagement of personal norms on the pro-environmental behaviour. Amongst them, Doran \& Larsen (2016) asserted that personal norm posits a strong positive relationship to choose eco-friendly travel options. Similarly, personal norms significantly impacted the purchase of pro-environment apparel (Kim \& Seock, 2019). The study conducted by Wynveen and Sutton (2015) signified that; individuals embracing personal norms plant trees, and use products that consume less energy to mitigate the adversities of climate change. Similarly, Shanmugavel \& Solayan (2021) signified a positive relationship between personal norms and green products purchase intention among the centennials in India. This shows that personal norm is an intrinsic motivation that usher people to adopt rainwater harvesting in their premises. Binding personal norms with intention to acquire RWH knowledge, environmental responsibility, environmental concern and adoption of rainwater harvesting, following hypotheses are proposed:

H1a. Personal norms positively influences the intention to acquire RWH knowledge.

H1b. Personal norms positively influences individuals' responsibility towards the environment.

H1c. Personal norms positively influences environmental concern possessed by the individuals.

H1d. Personal norms positively influences the adoption of rainwater harvesting.

\subsection{Subjective norms (SN)}


Subjective norms are the guidance that oneself derives or inherits from others to perform an action (Lam, 1999), therefore prior empirical evidence signifies its significant role on individuals' behavioral intentions and actions. Fishbein \& Ajzen (2011) defined subjective norms as the reference to individuals from known and important persons' actions and behaviours to perform a task. Earlier Ajzen (1991) construed that the internalized social pressure plays an active role in leveraging behaviours. Even in the day-to-day activities subjective norms do play a significant role.

Several researchers have explained the significant role of subjective norms on pro-environmental behaviours. For example, Marcos et al. (2021) investigated the influence of subjective norms on water conservation and found that it holds a strong binding with the individuals' intention to conserve water. However, the other study conducted by Kim \& Seock (2019) discovered that social norm significantly influenced pro-environmental purchasing behaviour. López-Mosquera et al. (2014) poignantly unveiled the significance of social norms by stating that individuals would intend to spend for environmental conservation. Experimental studies have also proved that subjective norms positively affect individuals to engage in pro-environmental behaviour (e.g. Reese et al., 2014; Mair and Bergin-Seers, 2010). Hence, this study assumes that subjective norms will be a strong predictor to adopt rainwater harvesting in their premises. Tying subjective norms with intention to acquire RWH knowledge, environmental responsibility, environmental concern and adoption of rainwater harvesting, following hypotheses are proposed:

H2a. Subjective norms positively influences the intention to acquire RWH knowledge.

H2b. Subjective norms positively influences individuals' responsibility towards the environment.

H2c. Subjective norms positively influences environmental concern possessed by the individuals.

H2d. Subjective norms positively influences the adoption of rainwater harvesting.

\subsection{Acquisition of rainwater harvesting knowledge (ARWHK)}

Knowledge is a supreme power which enables the cognitive skill of individuals (Zagzebski, 2017), similarly motivates the intellectualism that oneself possess (Fantl, 2012). Based on the arguments made by Zagzebski (2017), knowledge is acquirable as the acquisition of knowledge includes knowledge of persons, things and own self. However, knowledge acquisition from external sources is predominant among majority of the people. Therefore, knowledge is an understanding about a subject matter. The acceptance behaviour of individuals is influenced by the attitude towards knowledge adoption (Davis, 1989). In addition, MacRae (1999) has urged the need to design programs to create awareness about the sources that deteriorates the ecological status and to remediate the environment.

Several researchers have stated the linkage between knowledge and attitude (e.g. Bagheri et al., 2019; Shim et al., 2009). Individuals who acquire knowledge through sustainable development education programs necessarily shapes a sustainable future (Hadjichambis et al., 2015). A study conducted by Fielding \& Head (2012) affirmed that knowledge predicts more pro-environmental behaviour. However, 
some of the researchers also have stated that linear relationship does not exist between knowledge and action (e.g. Skamp et al., 2009; Chhokar et al., 2011). Hence, this study presumes that intention to acquire knowledge do play a significant role in the adoption of rainwater harvesting. Further, this study construes that intention to acquire RWH knowledge mediates the relationship between personal norms and subjective norms with the adoption of RWH. In view of the above discussion the following hypotheses are framed:

H3a. Intention to acquire RWHK positively influences the adoption of RWH.

H3b. Intention to acquire RWHK mediates the relationship between personal norms and adoption of RWH.

H3c. Intention to acquire RWHK mediates the relationship between subjective norms and adoption of RWH.

H3d. Intention to acquire RWHK positively influences the environmental responsibility.

H3e. Intention to acquire RWHK positively influences the environmental concern.

\subsection{Environmental responsibility (ER)}

Environmental responsibility is one of the significant attributes that facilitate to internalize and solve environmental related issues and problems by involving in making pro-environmental decisions and transforming the society to do so. Environmental responsibility is attributed as an inherent behavior of individuals' environmental interest manifested from their concern towards environmental security and welfare to redress environmental problems through day-to-day activities in maintaining the environment (Wong et al., 2018; Choudri et al., 2017). Inter alia, studies have also shown that environmental responsibility could be influenced through environmental education (Slavoljub et al., 2015).

Environmental responsibility could be manifested by keeping the environment clean; consuming less and optimal use of energy; involves in raising hands against environmental evils. In addition, DesJardins (1998) highlighted the importance of environmental responsibility in the corporate level and Furman \& Erdur (1999) at the individual level.

Some of the prior researchers have discovered the influence of environmental responsibility towards the pro-environmental behaviour. Amidst, Yue et al. (2020) demonstrated the significant effect of environmental responsibility on green consumption behaviour and environmental concern. Another study conducted by Kaiser and Scheuthle (2003) discovered the influence of environmental responsibility on the eco-friendly behavior. Further, Stern et al. (1999) confirmed the linear relationship between environmental responsibility and pro-environmental behavior, similarly Attaran and Celik (2015) reaffirmed the linear relationship between environmental responsibility and purchase intention of green buildings. In line with the above discussions this study assumes that environmental responsibility demonstrates a significant connection with the adoption of rainwater harvesting. Accordingly, following hypotheses are proposed: 
$\mathrm{H} 4 \mathrm{a}$. Environmental responsibility positively influences the adoption of RWH.

H4b. Environmental responsibility positively influences environmental concern.

H4c. Environmental responsibility mediates the relationship between personal norms and adoption of RWH.

H4d. Environmental responsibility mediates the relationship between subjective norms and adoption of RWH.

\subsection{Environmental concern (EC)}

Environmental concern is categorized as individuals' attitude (Minton \& Rose,1997) that might be developed through the perceived personal threats duly caused by environmental deterioration (Baldassare \& Katz, 1992). Hence, this study assumes that greater the environmental concern is a consequence of high level of environmental information acquired. In the meantime, several researchers have construed environmental concern as a strong positive predictor to pro-environmental behavior (e.g. McDonald et al., 2015; Felix et al., 2018). Accordingly, several researchers have studied the impact of environmental concern on pro-environmental behaviour and in accordance with the prior researchers this study assumes the adoption of rainwater harvesting as one of the pro-environmental behaviours.

In general, researchers have also felt that individuals possessing greater degree of environmental concern instantaneously take actions against mugging environmental problems and involves empathetically to protect the environment (McDonald et al., 2015). Similarly, a study conducted by Minton \& Rose (1997) proved that environmental concern significantly influences the purchase decision of eco-friendly products. Inter alia, Nagarajan \& Chidambaram (In Press) discerned the direct and indirect influence of environmental concern on the purchase intention of electric vehicles. Another study has also elicited the impact of environmental concern on environmentally responsible behaviour (Fransson \& Gärling, 1999). In the meantime, Suki (2016) showed the positive direct effect of environmental concern on green consumption intention. Moreover, prior studies have also shown that environmental concern influenced the willingness to pay for eco-friendly products (Xu et al., 2020). In view of the discussions this study proposes the following hypotheses.

H5a. Environmental concern positively influences the adoption of RWH.

H5b. Environmental concern mediates the relationship between personal norms and adoption of RWH.

H5c. Environmental concern mediates the relationship between subjective norms and adoption of RWH.

\subsection{Moderating variable: intention to acquire rainwater harvesting knowledge (IARWHK)}

Another interesting aspect in the contemporary information era is the influence of information and the intention to acquire knowledge. Hence, among others Hilgert et al. (2003) is of the opinion that 
individual's knowledge about a specific subject would influence their attitude toward performing a behavior. Further, the theory of consumer socialization states that individuals gain knowledge through various agencies (Ward, 1974). In the meantime, several studies have also proved the significant effect of environmental knowledge on pro-environmental behaviour (e.g. Vicente-Molina et al., 2013; Onel \& Mukherjee, 2016). Further, Masud et al. (2015) argued that knowledge about the adversities of climate change favours actions to mitigate climate change. Similarly, Pérez-Nordtvedt et al. (2008) is of the opinion that comprehensiveness of the subject matter rests with the learning intention. Albeit, the role of intention to acquire knowledge in enabling environmental responsibility and environmental concern with adoption intention of rainwater harvesting builds a gap in in academic literature. Therefore, this study assumes the moderating influence of IARWHK can help the environmentalists, government and academicians to better understand the individuals' contention and intention to adopt rainwater harvesting to facilitate sustainable groundwater. Hence, in light of the above discussions, this study surmises that environmental responsibility and environmental concern will exert a stronger effect on the adoption intention of rainwater harvesting.

$\mathrm{H6a}$. The impact of environmental responsibility on the adoption intention of rainwater harvesting is positively moderated by the intention to acquire rainwater harvesting knowledge.

H6b. The impact of environmental concern on the adoption intention of rainwater harvesting is positively moderated by the intention to acquire rainwater harvesting knowledge.

\subsection{Proposed research model}

To predict the individual's pro-environmental behaviour and behavioural change, several researchers have used and validated the Theory of Planned Behavior (TPB) (e.g. Ru et al., 2018; Wang et al., 2016; Armitage and Conner, 2001). Though the TPB intends to investigate the behavioural intent, subjective norms play a crucial role as suggested by Aliabadi et al. (2020) in the context of sustainable water management through rainwater harvesting in Iran. Moreover, several researchers including Ajzen (1991) have suggested to add pertinent variables that holistically explain the intended behavior (e.g. Tommasetti et al., 2018; Sánchez et al., 2018). At the same time, several researchers also have claimed the Norm Activation Model (NAM) as one of the best theoretical lenses to study the pro-environmental behavior in the light of its predictive power (e.g., Onwezen et al., 2013; De Groot and Steg, 2009). Though the NAM proposed by Schwart (1973) investigated the altruistic behaviour in a limited spectrum, it has been extended to study pro-environmental behaviours in its extended forms (Stern et al., 1999; Stern, 2000). Inter alia, few researchers have also argued that moral norms could enhance the predictive power of TPB further (e.g. Whitmarsh \& O'Neill, 2010; Fielding et al., 2008). Based on the suggestions made by prior researchers the personal norm has been added and inherited from the Norm Activation Model (Kim \& Seock, 2019), similarly, the environmental responsibility has also been added as derived from NAM (Yue et al., 2020). In addition, Zhang et al. (2017) affirmed NAM to examine individual's environmental complaint intention which is ascribed as pro-environmental behaviour. Based on the inputs from the prior study as environmental concern is a pro-environmental behaviour, this study claims environmental concern as one of the variables of NAM. In addition, intention to acquire knowledge about rainwater 
harvesting is added as this study assumes that intentions are scuttled by personal and subjective norms. Accordingly, the hypothetical has been proposed and shown as Fig. 1.

\section{Research Methodology}

\subsection{Research design and sample}

The proposed hypothetical model was investigated using a cross-sectional design. The data were collected using non-probability sampling procedure (convenience sampling) to garner responses required to perform the study. The data were collected during a five-day construction equipment event in India during December 2019. 420 samples comprising individuals who were constructing and likely to construct individual houses were identified during the event, subsequently they were also introduced the purpose of the study and requested to consummate the structured questionnaire. Finally, we could receive 403 usable data and used only 400 which was quite adequate to execute the study. Table 1 shows the demographic characteristics of the sample. 
Table 1

Socio-demographic characteristics of the sample

\section{Characteristics}

Frequency $(\mathrm{N}$

$=400$ )

Percentage

(\%)

Gender

Male

284

73.5

Female

106

26.5

Age

$20-25$

2

0.5

$26-30$

3

31-35

68

0.8

$36-40$

113

28.2

41-45

104

26

46-50

58

14.5

51-55

43

10.7

$>56$

9

2.3

Educational

Background

Under-graduate like B.A., B.Sc., B.Com., BCA., etc 57

14.2

Post-graduate degrees like M.A., M.Sc., M.Com., 88

MCA., etc

Professional Degrees like B.E., B. Tech., M.E., M. 253

Tech., M.B.A., etc

63.3

Others

2

0.5

Income

$<$ Rs. 20,000

10

2.5

Rs. $20001,-$ Rs. 30,000

29

7.2

Rs. 30001 - Rs. 40,000

49

12.3

Rs. $40001-$ Rs. 50,000

139

34.8

Rs. 50001 - Rs. 60,000

75

18.7

Rs. 60001 - Rs. 70,000

51

12.7

$>$ Rs. 70,000

11.8

Place of

Urban

306

76.5

residence

Rural

94

23.5

Construction

$<1000$ Square feet

261

65.3 


\subsection{Measurement}

The survey instrument consists of six constructs explained through 22 items. In order to befit the objectives of the study and to get rid of possible biases the validated measures from prior studies were meticulously selected and used. However, few items were modified to best suit to the context of rainwater harvesting. Likert's seven-point scale ranging between 1 (strongly disagree) and 7 (strongly agree) were adopted for all items. The questionnaire also included 4 demographic questions and 1 question relating to the construction of house. The constructs, its items and their sources are presented in Appendix A.

\subsection{Data analysis}

The data were analyzed with the use of Microsoft Excel, SPSS 23.0 and AMOS. Further, to study the proposed hypothetical model 1 the two-stage structural equation modelling was used as suggested by Anderson and Gerbing (1988). In the first stage confirmatory factor analysis (CFA) was performed to check the validity and reliability of the constructs, subsequently the structural model was analyzed. The current study uses 400 samples from the 403 samples collected which is a good size, hence as suggested by Leong et al. (2019) the co-variance-based structural equation modelling (SEM) was adopted. Similarly, as suggested by Hair et al. (2017) the current study fulfills the samples to the items used, and the loadings in the CFA suggests the employment of SEM. Further, we found the skewnesskurtosis values lesser than 2 and not exceeding 4 respectively confirm the data free from univariate normality issues, which further suggests to use SEM (Kline, 2005). The mediating role of intention to acquire rainwater harvesting knowledge on the path between personal norms and adoption intention of rainwater harvesting, and subjective norms and adoption intention of rainwater harvesting as signified by $\mathrm{H} 3 \mathrm{~b}, \mathrm{H} 3 \mathrm{c}, \mathrm{H} 4 \mathrm{c}$ and $\mathrm{H} 4 \mathrm{~d}$ is presented as model 2 and given in Fig. 1. Further, the moderating role of intention to acquire rainwater harvesting knowledge on the relationship between environmental responsibility, and environmental concern on the adoption intention of rainwater harvesting was studied through $\mathrm{H} 6 \mathrm{a}$ and $\mathrm{H} 6 \mathrm{~b}$, and presented as model 3 as given in Appendix C.

\section{Results}

\subsection{Respondents' profile and characteristics}

Socio-demographic details of the study units is presented in Table 1 . The study consists of $73.5 \%$ male and $26.5 \%$ female respondents. Relating to the distribution of age $28.3 \%$ of the respondents are between $31-35$ years of age. In addition, $63.5 \%$ of the respondents possess professional degrees like B.E., B. Tech., M.E., M. Tech., M.B.A., etc. It is also significant to note that $34.8 \%$ of the respondents' income falls between Rs. $40,001-50,000$ and $76.5 \%$ of the respondents' hail from urban areas. Regarding the 
construction area of the house $65.3 \%$ of the respondents were constructing or likely to construct houses below 1000 square feet. 
Table 2

Results of the Measurement Model

\begin{tabular}{|c|c|c|c|c|c|}
\hline Construct & Items & $\begin{array}{l}\text { Mean } \\
\text { (SD) }\end{array}$ & Loadings & $\begin{array}{l}\text { AVE, } \\
\text { MSV \& } \\
\text { ASV }\end{array}$ & $\begin{array}{l}\text { Composite } \\
\text { Reliability }\end{array}$ \\
\hline Personal norm & $\begin{array}{l}\text { PN1 } \\
\text { PN2 } \\
\text { PN3 }\end{array}$ & $\begin{array}{l}3.14 \\
(1.10) \\
3.01 \\
(1.23) \\
3.21 \\
(1.17)\end{array}$ & $\begin{array}{l}0.916^{\star \star \star} \\
0.692^{\star \star \star} \\
0.728^{\star \star \star}\end{array}$ & $\begin{array}{l}0.616 \\
0.285 \& \\
0.223\end{array}$ & 0.826 \\
\hline Subjective norm & $\begin{array}{l}\text { SN1 } \\
\text { SN2 } \\
\text { SN3 } \\
\text { SN4 }\end{array}$ & $\begin{array}{l}3.23 \\
(1.17) \\
\\
3.24 \\
(1.11) \\
\\
2.96 \\
(1.06) \\
2.83 \\
(1.04)\end{array}$ & $\begin{array}{l}0.683^{\star \star \star} \\
0.792^{\star \star \star} \\
0.740^{\star \star \star} \\
0.872^{\star \star \star}\end{array}$ & $\begin{array}{l}0.600 \\
0.373 \text { \& } \\
0.270\end{array}$ & 0.856 \\
\hline $\begin{array}{l}\text { Intention to acquire rainwater } \\
\text { harvesting knowledge }\end{array}$ & $\begin{array}{l}\text { IARWH1 } \\
\text { IARWH } \\
2 \\
\text { IARWH } \\
3\end{array}$ & $\begin{array}{l}3.85 \\
(1.75) \\
\\
3.02 \\
(1.57) \\
\\
2.89 \\
(1.49)\end{array}$ & $\begin{array}{l}0.651^{\star \star \star} \\
0.851^{\star \star \star} \\
0.731^{\star \star \star}\end{array}$ & $\begin{array}{l}0.561, \\
0.294 \& \\
0.214\end{array}$ & 0.810 \\
\hline Environmental responsibility & $\begin{array}{l}\text { ER1 } \\
\text { ER2 } \\
\text { ER3 } \\
\text { ER4 }\end{array}$ & $\begin{array}{l}3.01 \\
(1.30) \\
3.06 \\
(1.22) \\
2.89 \\
(1.09) \\
\\
2.78 \\
(1.02)\end{array}$ & $\begin{array}{l}0.944^{\star \star \star} \\
0.952^{\star \star \star} \\
0.843^{\star \star \star} \\
0.818^{\star \star \star}\end{array}$ & $\begin{array}{l}0.794, \\
0.397 \& \\
0.253\end{array}$ & 0.939 \\
\hline
\end{tabular}




\begin{tabular}{|c|c|c|c|c|c|}
\hline Construct & Items & $\begin{array}{l}\text { Mean } \\
\text { (SD) }\end{array}$ & Loadings & $\begin{array}{l}\text { AVE, } \\
\text { MSV \& } \\
\text { ASV }\end{array}$ & $\begin{array}{l}\text { Composite } \\
\text { Reliability }\end{array}$ \\
\hline Environmental concern & $\begin{array}{l}\text { EC1 } \\
\text { EC2 } \\
\text { EC3 } \\
\text { EC4 }\end{array}$ & $\begin{array}{l}3.12 \\
(1.03) \\
\\
3.30 \\
(1.11) \\
3.24 \\
(1.01) \\
\\
3.01 \\
(1.12)\end{array}$ & $\begin{array}{l}0.889^{\star \star \star} \\
0.959^{\star \star \star} \\
0.928^{\star \star \star} \\
0.841^{\star \star \star}\end{array}$ & $\begin{array}{l}0.820, \\
0.373 \& \\
0.319\end{array}$ & 0.948 \\
\hline $\begin{array}{l}\text { Adoption intention of rainwater } \\
\text { harvesting }\end{array}$ & $\begin{array}{l}\text { AIRWH1 } \\
\text { AIRWH2 } \\
\text { AIRWH3 } \\
\text { AIRWH4 }\end{array}$ & $\begin{array}{l}2.87 \\
(1.15) \\
2.90 \\
(1.23) \\
2.75 \\
(1.03) \\
\\
3.01 \\
(1.29)\end{array}$ & $\begin{array}{l}0.755^{\star \star \star} \\
0.713^{\star \star \star} \\
0.734^{\star \star \star} \\
0.897^{\star \star \star}\end{array}$ & $\begin{array}{l}0.605 \\
0.397 \& \\
0.325\end{array}$ & 0.859 \\
\hline $\begin{array}{l}\text { ** } \text { significant at } 99 \% \text { confidence } \\
\text { Confirmatory factor analysis fit } \\
0.918 \text { (Ideal }>0.900) ; \mathrm{CFI}=0.973 \\
\star \star \star \\
\\
\text { AVE denotes values significant at } \\
\text { Average Shared Variance. } \\
\text { Notes: } E C=\text { environmental conce } \\
\text { acquire rainwater harvesting kno } \\
\text { intention of rainwater harvesting }\end{array}$ & $\begin{array}{l}2 / \mathrm{df}=2.4 \\
.900) ; \mathrm{RM} \\
\text { nfidence le } \\
\text { MSV denc } \\
\text { personal } \mathrm{n} \\
\text { ER = enviro }\end{array}$ & $\begin{array}{l}\text { es Maxin } \\
\text { rm; SN = } \\
\text { mental r }\end{array}$ & $\begin{array}{l}\text { Im Shared V } \\
\text { ubjective no } \\
\text { ponsibility; }\end{array}$ & $\begin{array}{l}\text { Iriance; As } \\
\text { n; IARWH } \\
\text { IRWH = ac }\end{array}$ & $\begin{array}{l}\text { 900); AGFI = } \\
\text { denotes } \\
\text { intention to } \\
\text { ption }\end{array}$ \\
\hline
\end{tabular}

\subsection{Assessment of measurement model}

Initially the Cronbach's alpha value was tested (shown in Table 3) to ensure the sufficiency of internal consistency, resultantly the individual constructs score more than 0.77 and confirms to the suggestions of Nunnally \& Bernstein (1994). Subsequently, the convergent and discriminant validity were examined. Table 2 as shows the item loadings for all the constructs above 0.65 and the average variance extracted (AVE) above 0.56 indicates an excellent content and convergent validity (Hew \& Kadir, 2016). Further a good discriminant validity is assured, as the values of AVE were greater than the MSV (Maximum Shared Variance) and ASV (Average Shared Variance) (Hew \& Kadir, 2016). Similarly, the values of composite 
reliability as greater than 0.8 determines an excellent fit. Inter alia, the discriminant validity could be checked from Table 3. through the correlation matrix. The diagonal values as signify the square root of AVE's and greater than the corresponding inter-correlations ensures the discriminant validity. Thus how, the measurement model shows an adequate level of reliability and validity. Further based on the studies of Leong et al. (2012) we employed the fit indices like; $\chi^{2} / \mathrm{df}$, goodness of fit index (GFI), adjusted goodness of fit index (AGFI), comparative fit index (CFI) and root mean square approximation (RMSEA) to measure uni-dimensionality and to minimize measuring bias. The corresponding values for these fit indices given in Table 2, satisfy the threshold values (e.g. Leong et al., 2019; Hair et al., 2010).

Table 3

Inter-correlation and $\sqrt{ }$ AVE values

\begin{tabular}{|c|c|c|c|c|c|c|c|}
\hline Constructs & Cronbach's a & EC & PN & SN & IARWH & ER & AIRWH \\
\hline EC & 0.945 & 0.905 & & & & & \\
\hline PN & 0.809 & 0.534 & 0.785 & & & & \\
\hline SN & 0.852 & 0.611 & 0.473 & 0.775 & & & \\
\hline IARWH & 0.773 & 0.534 & 0.380 & 0.456 & 0.749 & & \\
\hline ER & 0.937 & 0.542 & 0.457 & 0.469 & 0.372 & 0.891 & \\
\hline AIRWH & 0.852 & 0.598 & 0.503 & 0.570 & 0.542 & 0.630 & 0.778 \\
\hline \multicolumn{8}{|c|}{ Note 1: The diagonal values represent the $\sqrt{ }$ AVE. } \\
\hline \multicolumn{8}{|c|}{$\begin{array}{l}\text { Note 2: } \mathrm{EC}=\text { environmental concern; } \mathrm{PN}=\text { personal norm; } \mathrm{SN}=\text { subjective norm; IARWH = intention to } \\
\text { acquire rainwater harvesting knowledge; } \mathrm{ER}=\text { = environmental responsibility; AIRWH = adoption } \\
\text { intention of rainwater harvesting }\end{array}$} \\
\hline
\end{tabular}

\subsection{Common method bias analysis}

The current study relies on data that are self-reported, hence there is a need to assure the data free from common method bias (CMB) issues (Podsakoff et al., 2003). Similarly, Chopdar \& Balakrishnan (2020) suggested to check $\mathrm{CMB}$ issues when common tools were used to measure all variables. Therefore, we used Harman's single factor analysis (Harman, 1976) which has extensively been used by several researchers (e.g. Podsakoff et al., 2003; Malhotra et al., 2006; Wong et al., 2015). With the use of SPSS 23 exploratory factor analysis was performed by considering all the 22 items using unrotated factor solution. Resultantly, the first factor explained 39.87 per cent of the variance which is lesser than 50 percent, satisfies Podsakoff et al. (2003) 's recommendation and confirms the data free from CMB issues (Hew \& Kadir, 2016; Lin et al., 2014).

\subsection{Structural model evaluation}


The second stage of the SEM shows the results of hypothesis testing of model 1 as exhibited in Table 4. The relationship between personal norm and intention to acquire rainwater harvesting knowledge was found to be statistically significant $(\beta=0.229 ; p<0.001)$, thereby $\mathrm{H} 1$ a got accepted. Similarly, the relationship between personal norm and environmental responsibility was also found to be significant ( $\beta$ $=0.288 ; \mathrm{p}<0.001)$, thereby $\mathrm{H} 1 \mathrm{~b}$ was accepted. In addition, the relationship between personal norm and environmental concern was found as significant $(\beta=0.227 ; p<0.001)$, whereby $\mathrm{H} 1 \mathrm{c}$ got accepted. Further, a significant relationship exists between personal norm and adoption intention of rainwater harvesting ( $\beta$ $=0.123 ; p<0.05)$ and $\mathrm{H} 1 \mathrm{~d}$ was also accepted. Next, the subjective norm was tested with the intention to acquire rainwater harvesting knowledge $(\beta=0.375 ; p<0.001)$; environmental responsibility $(\beta=0.298 ; p<$ $0.001)$; environmental concern $(\beta=0.327 ; p<0.001)$ and adoption intention of rainwater harvesting $((\beta=$ 0.189; $\mathrm{p}<0.001)$; thus $\mathrm{H} 2 \mathrm{a}, \mathrm{H} 2 \mathrm{~b}, \mathrm{H} 2 \mathrm{c}$ and $\mathrm{H} 2 \mathrm{~d}$ got accepted. Similarly, statistical relationship was examined between the intention to acquire rainwater harvesting knowledge with adoption intention of rainwater harvesting knowledge $(\beta=0.231 ; p<0.001)$, environmental responsibility $(\beta=0.148 ; p<0.05)$ and environmental concern $(\beta=0.247 ; p<0.05)$, whereby $\mathrm{H} 3 \mathrm{a}, \mathrm{H} 3 \mathrm{~b}$ and $\mathrm{H} 3 \mathrm{c}$ got accepted. Then a robust positive relationship exists between the environmental responsibility and adoption intention of rainwater harvesting $(\beta=0.352 ; p<0.001)$; and environmental concern $(\beta=0.226 ; p<0.001)$, therefore $H 4 a$ and $H 4 b$ got accepted. Finally, a statistical significance exists between environmental concern and adoption intention of rainwater harvesting $(\beta=0.124 ; p<0.05)$ and $\mathrm{H} 5$ got accepted. Further, through linear regression analysis the variance inflation factors were estimated and proves the absence of multicollinearity issues between the independent and dependent factors. Additionally, Table 4 shows the estimated values of VIF lesser than 10 confirms the study free from multicollinearity issues based on the results as signified by Brace et al. (2000). Further, the hypothetical model holds an excellent fit. $X^{2} / d f=$ 2.871 (Ideal < 3.0); GFI = 0.928 (Ideal >0.900); AGFI = 0.910 (Ideal > 0.900); CFI = 0.938 (Ideal > 0.900); RMSEA $=0.068$ (Ideal < 0.08). Finally, a good predictive validity was also derived by the conceptual model as the variance calculated were $0.231,0.34,0.47$ and 0.52 respectively for the intention to acquire rainwater harvesting knowledge, environmental responsibility, environmental concern and adoption intention of rainwater harvesting. 
Table 4

Results of hypotheses testing

\begin{tabular}{|c|c|c|c|}
\hline Endogenous constructs & Exogenous constructs & $\begin{array}{l}\text { Standardised } \\
\text { Estimates }\end{array}$ & VIF \\
\hline $\begin{array}{l}\text { Intention to acquire rainwater } \\
\text { harvesting knowledge }\end{array}$ & Personal norm & $0.229^{\star \star \star}$ & 2.641 \\
\hline Environmental Responsibility & Personal norm & $0.288^{\star \star \star}$ & 2.312 \\
\hline Environmental concern & Personal norm & $0.227^{\star * \star}$ & 1.486 \\
\hline $\begin{array}{l}\text { Adoption intention of rainwater } \\
\text { harvesting }\end{array}$ & Personal Norm & $0.123^{* *}$ & 1.931 \\
\hline $\begin{array}{l}\text { Intention to acquire rainwater } \\
\text { harvesting knowledge }\end{array}$ & Subjective norm & $0.375^{\star \star \star}$ & 1.671 \\
\hline Environmental Responsibility & Subjective norm & $0.298^{\star \star \star}$ & 2.327 \\
\hline Environmental concern & Subjective norm & $0.327^{\star \star \star}$ & 1.647 \\
\hline $\begin{array}{l}\text { Adoption intention of rainwater } \\
\text { harvesting }\end{array}$ & Subjective norm & $0.189^{\star \star \star}$ & 2.138 \\
\hline $\begin{array}{l}\text { Adoption intention of rainwater } \\
\text { harvesting }\end{array}$ & $\begin{array}{l}\text { Intention to acquire rainwater } \\
\text { harvesting knowledge }\end{array}$ & $0.231^{\star \star \star}$ & 2.383 \\
\hline Environmental responsibility & $\begin{array}{l}\text { Intention to acquire rainwater } \\
\text { harvesting knowledge }\end{array}$ & $0.148^{\star *}$ & 2.431 \\
\hline Environmental concern & $\begin{array}{l}\text { Intention to acquire rainwater } \\
\text { harvesting knowledge }\end{array}$ & $0.247^{\star \star \star}$ & 2.657 \\
\hline $\begin{array}{l}\text { Adoption intention of rainwater } \\
\text { harvesting }\end{array}$ & Environmental responsibility & $0.352^{\star \star \star}$ & 2.521 \\
\hline Environmental concern & Environmental responsibility & $0.226^{\star \star \star}$ & 1.786 \\
\hline $\begin{array}{l}\text { Adoption intention of rainwater } \\
\text { harvesting }\end{array}$ & Environmental concern & $0.124^{\star *}$ & 2.641 \\
\hline \multicolumn{4}{|c|}{${ }^{\star \star \star}$ denotes $p<0.001 ;{ }^{\star \star}$ denotes $p<0.05$} \\
\hline VIF = variance inflation factor & & & \\
\hline
\end{tabular}

\subsection{Analysing the direct and indirect effect (model 2)}

The total, direct and indirect effects notified in model 2 were analyzed using AMOS with 3000 bootstrapped sample with $95 \%$ significance level (Preacher \& Hayes, 2008) as shown in Table 5. Initially, the indirect effect of intention to acquire rainwater harvesting knowledge on the path between personal 
norm and adoption intention of rainwater harvesting, and subjective norm and adoption intention of rainwater harvesting was examined. The results indicated that intention to acquire rainwater harvesting knowledge created a positive impact between personal norm and adoption intention of rainwater harvesting, and subjective norm and adoption intention of rainwater harvesting. At the same time, a positive direct effect exists between both personal norm and adoption intention of rainwater harvesting; and subjective norm and adoption intention of rainwater harvesting and signifies the presence of partial complementary mediation. Subsequently, the indirect effect of environmental responsibility on the path between personal norm and adoption intention of rainwater harvesting; and subjective norm and adoption intention of rainwater harvesting was checked. The study shows the existence of positive direct relationship between personal norm and adoption intention of rainwater harvesting and; subjective norm and adoption intention of rainwater and similarly indirect relationships through environmental responsibility. This further proves the existence of partial complementary mediation. Finally, the direct and indirect relationships of personal norm; and subjective norm with adoption intention of rainwater harvesting was checked and confirmed the indirect effect of environmental concern on the relationships between personal norm; and subjective norm with adoption intention of rainwater harvesting. As both the direct and indirect effects are positive this study again proves the existence of partial complementary mediation. 
Table 5

Results of Mediation Analysis

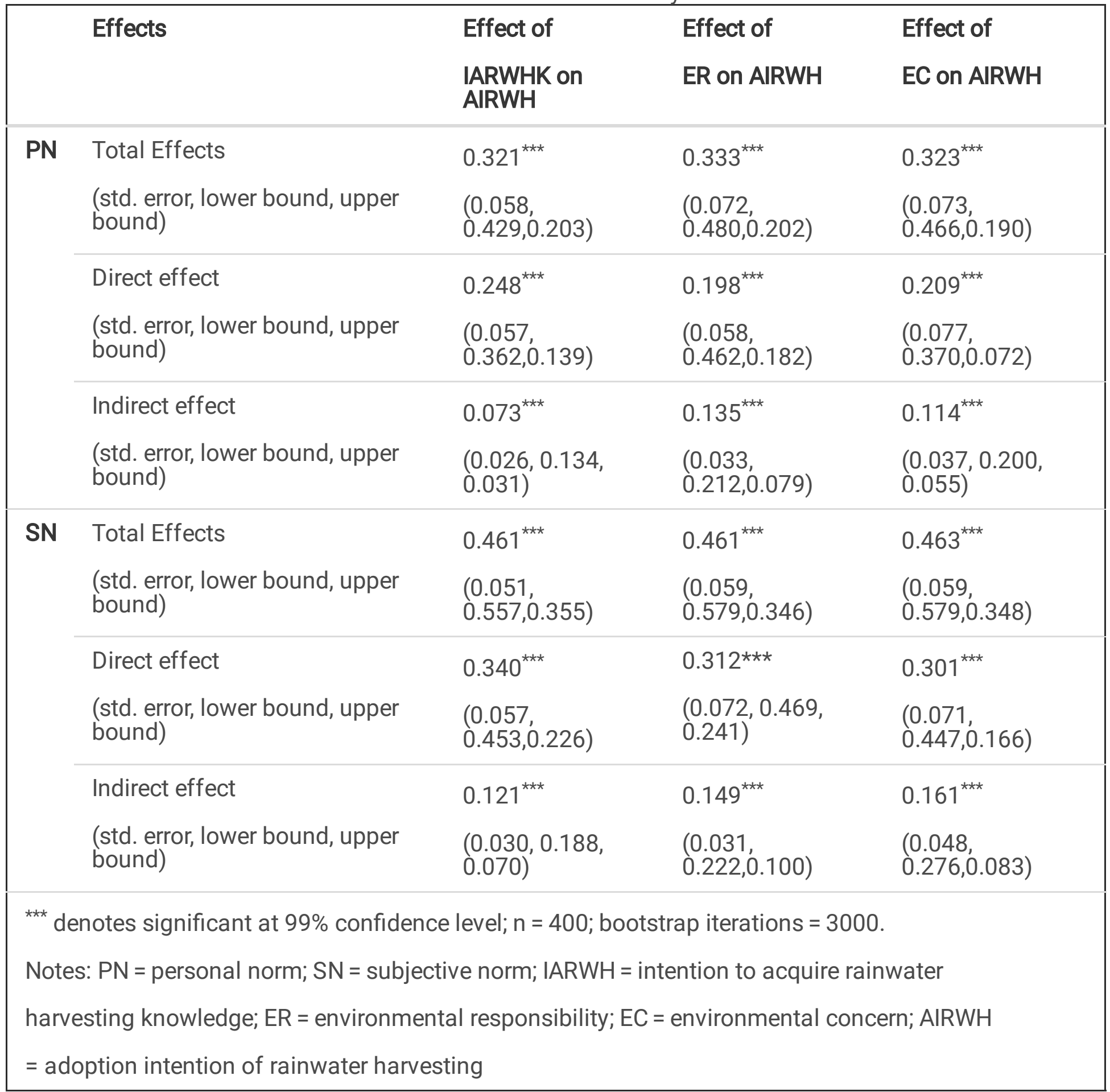

\subsection{Analyzing the moderating influence of intention to acquire rainwater harvesting knowledge (model 3)}

Based on the discussions made, this study assumes the existence of the moderating effect of intention to acquire rainwater harvesting knowledge on environmental responsibility and environmental concern specified through H6a to H6b. Through the product term (Independent Variable X Moderator) the existence of moderation is tested. Intention to acquire rainwater harvesting knowledge (IARWHK) 
significantly moderated the relationship between environmental responsibility and adoption intention of rainwater harvesting $(\beta=0.518 ; p<0.001)$ and; environmental concern and adoption intention of rainwater harvesting $(\beta=0.656 ; p<0.001)$, thereby, $\mathrm{H} 6 \mathrm{a}$ and $\mathrm{H6b}$ got accepted. This implies that IARWHK strengthens the positive impact of environmental responsibility and environmental concern on adoption intention of rainwater harvesting. Further it could be inferred that greater the intention to acquire rainwater harvesting knowledge augments the effect of environmental responsibility and environmental concern on the adoption intention of rainwater harvesting. The results of the moderation are well depicted through interaction graphs in Appendix B.

\section{Discussions}

Several researches authenticate the employment of the Theory of Planned Behaviour and Norm Activation Model on individuals' pro-environmental behaviour. However, very scant researches have used the combination of factors like personal norm, subjective norm, environmental responsibility and environmental concern. Additionally, this study has employed the intention to acquire rainwater harvesting knowledge to predict the adoption intention of rainwater harvesting which remains new in the context of pro-environmental behaviour and decisions. However, in the research on rainwater harvesting, scholars have focused on gender, awareness and social status (Kanyi et al., 2016) and much on procedures and outcomes (e.g. Ding et al., 2021; Jones \& Hunt, 2010; Pandey et al., 2003). It is based on the contention that no systematic investigation has been made to study the rainwater harvesting with the acquaintance of intention to acquire rainwater harvesting knowledge. In this perspective this study fills this gap, and the results show that intention to acquire rainwater harvesting knowledge is kindled by personal norm and subjective norm which further moderates environmental responsibility and environmental concern to predict the adoption intention of rainwater harvesting. In line with the findings of Aliabadi et al. (2020) personal norm was found to be one of the influential drivers to predict the adoption intention of rainwater harvesting. It is further found that personal norm influences environmental responsibility and concern. Consequently, environmental responsibility and concern were determined as the strong predictors of adoption intention of rainwater harvesting and also mediates the relationship of personal norm and subjective norm on the adoption intention of rainwater harvesting. Subsequently, subjective norm enables the adoption intention of rainwater harvesting and supports the findings of Lam (2006) in the context of water conservation. Similarly subjective norms influence the intention to acquire rainwater harvesting knowledge, environmental responsibility and concern and finally resorts in the adoption intention of rainwater harvesting.

\subsection{Theoretical contributions}

This empirical work contributes significantly towards the academic edge of the adoption intention of rainwater harvesting which is imperative in the egregious downfall due to excessive and deficit rainfall. The outcomes of this study add new knowledge in view of the behavioural perspective of rainwater harvesting literature by signifying the vital drivers of environmental responsibility and concern, and further reveals their impact on the adoption intention of rainwater harvesting. Similar to the results of 
prior studies, personal and subjective norms are noted to be the significant contributors to environmental responsibility and concern and strong predictors to the adoption intention to rainwater harvesting. It is an interesting and novel finding that intention to acquire rainwater harvesting is activated by personal and subjective norms which further leads to the adoption intention of rainwater harvesting. Another notable contribution of this work is the moderating effect of intention to acquire rainwater harvesting knowledge on environmental responsibility and concern. Further the mediating aspect of intention to acquire rainwater harvesting, environmental responsibility and environmental concern on the relationships between personal norm; subjective norm and adoption intention of rainwater harvesting are also the significant contributions.

\subsection{Societal implications}

Developing environmental responsibility is presumed as a challenge though it results in environmental and ecological concern (DesJardins, 1998). However, this study finds different way to develop environmental responsibility and concern and draws few significant implications that will be useful to the policy makers and the society at large in promoting sustainable ground water. First, the study considered the factors such as; environmental concern, personal norm, subjective norms, intention to acquire rainwater harvesting knowledge, environmental responsibility to explain or to predict the intention to adopt rainwater harvesting. All these factors significantly contributed to adopt rainwater harvesting. Several studies thought ascribed the significance of rainwater harvesting (e.g. Kumar et al., 2006; Kanyi et al., 2016) this study too affirms the imperativeness of rainwater harvesting for sustainable ground water. Hence, the role of government and non-government organizations in this regard is significant to transform the general public orient towards the sustainable ground water. This study indicates that policy makers need to provide poignant information about rainwater harvesting to make the general public internalize the adoption of rainwater harvesting as personal norm, environmental concern and environmental responsibility play significant role in the intention to adopt rainwater harvesting in the study. Similarly, the individual households who adopted rainwater harvesting should be publicized by means of placing a placard or similar tools to induce the subjective norm, because subjective norm plays key role in the transformation of people towards the adoption of rainwater harvesting. In addition, incentives should be provided to the households by means of reductions in house taxes and others. Further the Government can install rainwater harvesting system to individual households in a subsidized rate to enthuse the households about its significance, because environmental concern, personal norm and environmental responsibility could be enthused by means of these sorts of activities. The Government needs to do public service advertisement through, television channels, print media and social media as the intention to acquire rainwater harvesting knowledge induces environmental responsibility and environmental concern. Inter alia, the reach of all these platforms in disseminating social messages is phenomenal. Finally, the community can establish a model for the households who installed and promote implementing rainwater harvesting.

\section{Conclusions}


Triggered by the egregious exploitation of ground water and the substantial runoff water leading to excessive floods during rainy season on one side and the deprivation of water for drinking, farming and industrial purposes on the other side, this study intends to gain a better understanding of the sustainable ground water by means of rainwater harvesting among the people. In summary, our study extends the research by the application of both the Theory of Planned Behaviour and Norm Activation Model and explored the significance of intention to acquire rainwater harvesting knowledge to the adoption intention of RWH. Our findings suggest that personal norms, subjective norms, intention to acquire rainwater harvesting knowledge, environmental responsibility and environmental concern significantly influence the adoption of rainwater harvesting. Similarly, the findings suggest that intention to acquire rainwater harvesting knowledge moderates both environmental responsibility and environmental concern to adopt rainwater harvesting. The study results further show the mediating effect of intention to acquire rainwater harvesting knowledge, environmental responsibility and environmental concern on the paths between personal norm; and subjective norm and adoption of rainwater harvesting.

\subsection{Limitations and future research directions}

Finally, we signify the limitations of our study. First, our sample represents the participants in a five-day construction equipment event in India. Though it represents people across the country, we cannot fully represent samples from the length and breadth of India. Therefore, the findings may attach some residence bias. Future extensive research covering all cities, major towns and villages can be undertaken to investigate people across different levels. In addition, our study identifies the factors such as personal norm, subjective norm, intention to acquire rainwater harvesting knowledge, environmental responsibility and environmental concern however, there are other factors like cost to install rainwater harvesting system, incentives to install, need for rainwater harvesting and others can be adopted to better explain the adoption intention of rainwater harvesting. Similarly, other prediction models can be adopted as simple technologies are used in the installation of RWH system. Future research can focus on the link between the influence of technological knowhow of rainwater harvesting and environmental knowledge due to the increasing rebound effect.

\section{Declarations}

Ethical Approval: The ethical approval was granted by the research team's university ethics committee.

Consent to Participate: The author and the co-author consent to participate with the Journal of Water Resources Management in the publication of this research paper.

Consent to Publish: The researchers discharge their consent to publish this research paper in the Journal of Water Resources Management.

Funding: This research did not receive any specific grant from funding agencies in the public, commercial, or not-for-profit sectors. 


\section{Credit authorship contribution statement:}

Nagarajan Shanmugavel: Conceptualization, Methodology, Validation, Resources, Data curation, Writing original draft, Visualization, Supervision, Project administration, Funding acquisition.

Rema Rajendran: Conceptualization, Software, Formal analysis, Investigation, Writing - review \& editing, Funding acquisition.

Declaration of Competing Interest: The authors declare no conflict of interest

\section{References}

1. Ajzen I (1991) The Theory of Planned Behavior. Organ Behav Hum Decis Process 50(2):179-211

2. Aliabadi V, Gholamrezai S, Ataei P (2020) Rural people's intention to adopt sustainable water management by rainwater harvesting practices: application of TPB and HBM models. Water Supply 20(5):1847-1861

3. Alley WM, Reilly TE, Franke OL (1999) Sustainability of ground-water resources, vol 1186. US Department of the Interior, US Geological Survey

4. Anderson JC, Gerbing DW (1988) Structural equation modeling in practice: A review and recommended two-step approach. Psychol Bull 103(3):411

5. Armitage CJ, Conner M (2001) Efficacy of the theory of planned behaviour: A meta-analytic review. $\mathrm{Br}$ J Soc Psychol 40(4):471-499

6. Attaran S, Celik BG (2015) Students' environmental responsibility and their willingness to pay for green buildings. Int J Sustain High Educ 16(3):327-340

7. Bagheri A, Bondori A, Allahyari MS, Damalas CA (2019) Modeling farmers' intention to use pesticides: An expanded version of the theory of planned behavior. J Environ Manage 248:109291

8. Baldassare M, Katz C (1992) The personal threat of environmental problems as predictor of environmental practices. Environment Behavior 24(5):602-616

9. Barr S, Gilg A, Shaw G (2011) 'Helping people make better choices': exploring the behaviour change agenda for environmental sustainability. Appl Geogr 31(2):712-720

10. Boers TM, Ben-Asher J (1982) A review of rainwater harvesting. Agric Water Manag 5(2):145-158

11. Centre for Science and Environment. Available at: https://www.cseindia.org/legislation-on-rainwaterharvesting, (Accessed 21 May 2021)

12. Chhokar K, Dua S, Taylor N, Boyes E, Stanisstreet M (2011) Indian secondary students'views about global warming: beliefs about the usefulness of actions and willingness to act. International Journal of Science Mathematics Education 9(5):1167-1188

13. Chopdar PK, Balakrishnan J (2020) Consumers response towards mobile commerce applications: SOR approach. Int J Inf Manage 53:1-16 
14. Choudri BS, Baawain M, Al-Zeidi K, Al-Nofli H, Al-Busaidi R, Al-Fazari K (2017) Citizen perception on environmental responsibility of the corporate sector in rural areas. Environ Dev Sustain 19(6):25652576

15. Conner M, Armitage CJ (1998) Extending the theory of planned behavior: A review and avenues for further research. J Appl Soc Psychol 28(15):1429-1464

16. Conner M, Kirk SF, Cade JE, Barrett JH (2003) Environmental influences: factors influencing a woman's decision to use dietary supplements. The Journal of Nutrition 133(6):1978-1982

17. Davis FD (1989) Perceived usefulness, perceived ease of use, and user acceptance of information technology. MIS Q 13(3):319-340

18. De Groot JI, Steg L (2009) Morality and prosocial behavior: The role of awareness, responsibility, and norms in the norm activation model. The Journal of Social Psychology 149(4):425-449

19. Dean M, Raats MM, Shepherd R (2012) The Role of Self- Identity, Past Behavior, and Their Interaction in Predicting Intention to Purchase Fresh and Processed Organic Food 1. J Appl Soc Psychol 42(3):669-688

20. DesJardins J (1998) Corporate environmental responsibility. J Bus Ethics 17(8):825-838

21. Ding W, Wang F, Dong Y, Jin K, Cong C, Han J, Ge W (2021) Effects of rainwater harvesting system on soil moisture in rain-fed orchards on the Chinese Loess Plateau. Agric Water Manag 243:1-10

22. Doran R, Larsen S (2016) The relative importance of social and personal norms in explaining intentions to choose eco-friendly travel options. International Journal of Tourism Research 18(2):159-166

23. Fantl J (2012) Knowledge how

24. Felix R, Hinsch C, Rauschnabel PA, Schlegelmilch BB (2018) Religiousness and environmental concern: A multilevel and multi-country analysis of the role of life satisfaction and indulgence. $J$ Bus Res 91:304-312

25. Fielding KS, McDonald R, Louis WR (2008) Theory of planned behaviour, identity and intentions to engage in environmental activism. Journal of Environmental Psychology 28(4):318-326

26. Fishbein M, Ajzen I (2011) Predicting and changing behavior: The reasoned action approach. Taylor \& Francis

27. Fransson N, Gärling T (1999) Environmental concern: Conceptual definitions, measurement methods, and research findings. Journal of Environmental Psychology 19(4):369-382

28. Furman A, Erdur O (1999) Are good citizens environmentalists? Human Ecology 27(1):181-188

29. Glendenning CJ, Vervoort RW (2010) Hydrological impacts of rainwater harvesting (RWH) in a case study catchment: The Arvari River, Rajasthan, India. Part 1: Field-scale impacts. Agric Water Manag 98(2):331-342

30. Godin G, Kok G (1996) The theory of planned behavior: a review of its applications to health-related behaviors. American Journal of Health Promotion 11(2):87-98 
31. Hadjichambis AC, Paraskeva-Hadjichambi D, loannou H, Georgiou Y, Manoli CC (2015) Integrating sustainable consumption into environmental education: A case study on environmental representations, decision making and intention to act. International Journal of Environmental Science Education 10(1):67-86

32. Hair JF, Hult GTM, Ringle CM, Sarstedt M, Thiele KO (2017) Mirror, mirror on the wall: A comparative evaluation of composite-based structural equation modeling methods. J Acad Mark Sci 45(5):616632

33. Hair JF, William CB, Barry JB, Rolph EA (2010) Multivariate data analysis. Prentice Hall, Englewood Cliffs

34. Hamzah MI, Tanwir NS (2021) Do pro-environmental factors lead to purchase intention of hybrid vehicles? The moderating effects of environmental knowledge. J Clean Prod 279:1-29

35. Harman HH (1976) Modern factor analysis, 3rd edn. University of Chicago Press, Chicago

36. Hew TS, Kadir SLSA (2016) Understanding cloud-based VLE from the SDT and CET perspectives: Development and validation of a measurement instrument. Comput Educ 101:132-149

37. Hilgert MA, Hogarth JM, Beverly SG (2003) Household financial management: The connection between knowledge and behavior. Federal Reserve Bulletin 89:309-322

38. Jones MP, Hunt WF (2010) Performance of rainwater harvesting systems in the southeastern United States. Resour Conserv Recycl 54(10):623-629

39. Kaiser FG, Scheuthle H (2003) Two challenges to a moral extension of the theory of planned behavior: Moral norms and just world beliefs in conservationism. Personality Individ Differ 35(5):1033-1048

40. Kanyi M, Lawver DE, Ulmer J, Murimi M, Ritz R (2016) Attitudes and adoption of rainwater harvesting: Influence of gender, awareness, and social status. Journal of International Agricultural Extension Education 24(1):63-73

41. Kim SH, Seock YK (2019) The roles of values and social norm on personal norms and proenvironmentally friendly apparel product purchasing behavior: The mediating role of personal norms. Journal of Retailing Consumer Services 51:83-90

42. Kline RB (2005) Principles and practice of structural equation modelling. The Guilford Press, New York

43. Kumar MD, Ghosh S, Patel A, Singh OP, Ravindranath R (2006) Rainwater harvesting in India: some critical issues for basin planning and research. Land Use Water Resources Research 6:1-17

44. Lam SP (1999) Predicting intentions to conserve water from the theory of planned behavior, perceived moral obligation, and perceived water right 1. J Appl Soc Psychol 29(5):1058-1071

45. Lam SP (2006) Predicting intention to save water: Theory of planned behavior, response efficacy, vulnerability, and perceived efficiency of alternative solutions. J Appl Soc Psychol 36(11):2803-2824

46. Lee E, Park NK, Han JH (2013) Gender difference in environmental attitude and behaviors in adoption of energy-efficient lighting at home. Journal of Sustainable Development 6(9):36-50 
47. Leong LY, Hew TS, Ooi KB, Lin B (2012) The determinants of customer loyalty in Malaysian mobile telecommunication services: A structural analysis. International Journal of Services Economics Management 4(3):209-236

48. Leong LY, Hew TS, Ooi KB, Lin B (2019) Do electronic word-of-mouth and elaboration likelihood model influence hotel booking? Journal of Computer Information Systems 59(2):146-160

49. Liao S, Chou EY (2012) Intention to adopt knowledge through virtual communities: posters vs lurkers. Online Inf Rev 36(3):442-461

50. Lin H, Fan W, Chau PY (2014) Determinants of users' continuance of social networking sites: A selfregulation perspective. Inf Manag 51(5):595-603

51. Lindenberg S, Steg $L$ (2007) Normative, gain and hedonic goal frames guiding environmental behavior. Journal of Social issues 63(1):117-137

52. López-Mosquera N, García T, Barrena R (2014) An extension of the Theory of Planned Behavior to predict willingness to pay for the conservation of an urban park. J Environ Manage 135:91-99

53. Mair J, Bergin-Seers S (2010) The effect of interventions on the environmental behaviour of Australian motel guests. Tourism Hospitality Research 10(4):255-268

54. Malhotra NK, Kim SS, Patil A (2006) Common method variance in IS research: A comparison of alternative approaches and a reanalysis of past research. Manage Sci 52(12):1865-1883

55. Marcos KJ, Moersidik SS, Soesilo TE (2021, March) Extended theory of planned behavior on utilizing domestic rainwater harvesting in Bekasi, West Java, Indonesia. In IOP Conference Series: Earth and Environmental Science (Vol. 716, No. 1, p. 012054). IOP Publishing

56. Masud MM, Akhtar R, Afroz R, Al-Amin AQ, Kari FB (2015) Pro-environmental behavior and public understanding of climate change. Mitig Adapt Strat Glob Change 20(4):591-600

57. Masud MM, Al-Amin AQ, Junsheng H, Ahmed F, Yahaya SR, Akhtar R, Banna H (2016) Climate change issue and theory of planned behaviour: relationship by empirical evidence. J Clean Prod 113:613-623

58. McDonald S, Oates CJ, Thyne M, Timmis AJ, Carlile C (2015) Flying in the face of environmental concern: why green consumers continue to fly. Journal of Marketing Management 31(13-14):15031528

59. McRae K (ed) (1990) Outdoor and environmental education: Diverse purposes and practices. MacMillan/Australia

60. Mehmetoglu M (2010) Factors Influencing the Willingness to Behave Environmentally Friendly at Home and Holiday Settings. Scandinavian Journal of Hospitality Tourism 10(4):430-447

61. Minton AP, Rose RL (1997) The effects of environmental concern on environmentally friendly consumer behavior: An exploratory study. J Bus Res 40(1):37-48

62. Nagarajan PS, Chidambaram AL (In Press). An exploration on electric vehicle purchase intention. International Journal of Electric and Hybrid Vehicles

63. Nunnally JC, Bernstein IH (1994) Psychometric theory, 3rd edn. McGraw-Hill, New York 
64. Onel N, Mukherjee A (2016) Consumer knowledge in pro-environmental behavior. World Journal of Science, Technology and Sustainable Development, 13(4), 328-352

65. Onwezen MC, Antonides G, Bartels J (2013) The Norm Activation Model: An exploration of the functions of anticipated pride and guilt in pro-environmental behaviour. J Econ Psychol 39:141-153

66. Pandey DN, Gupta AK, Anderson DM (2003) Rainwater harvesting as an adaptation to climate change. Curr Sci 85(1):46-59

67. Pérez-Nordtvedt L, Kedia BL, Datta DK, Rasheed AA (2008) Effectiveness and efficiency of crossborder knowledge transfer: An empirical examination. J Manage Stud 45(4):714-744

68. Podsakoff PM, MacKenzie SB, Lee JY, Podsakoff NP (2003) Common method biases in behavioral research: A critical review of the literature and recommended remedies. J Appl Psychol 88(5):879903

69. Pophare AM, Lamsoge BR, Katpatal YB, Nawale VP (2014) Impact of over-exploitation on groundwater quality: a case study from WR-2 Watershed, India. J Earth Syst Sci 123(7):1541-1566

70. Preacher KJ, Hayes AF (2008) Asymptotic and resampling strategies for assessing and comparing indirect effects in multiple mediator models. Behav Res Methods 40:879-891

71. Reese G, Loew K, Steffgen G (2014) A towel less: Social norms enhance pro-environmental behavior in hotels. The Journal of Social Psychology 154(2):97-100

72. Ru X, Qin H, Wang S (2019) Young people's behaviour intentions towards reducing PM2. 5 in China: Extending the theory of planned behaviour. Resour Conserv Recycl 141:99-108

73. Sánchez M, López-Mosquera N, Lera-López F, Faulin J (2018) An extended planned behavior model to explain the willingness to pay to reduce noise pollution in road transportation. Journal of cleaner production 177:144-154

74. Schwartz SH (1973) Normative explanations of helping behavior: A critique, proposal, and empirical test. J Exp Soc Psychol 9(4):349-364

75. Shanmugavel N, Solayan S (2021) Impact of Hedonic Motivation and Perceived moral obligation on Green Products Purchase Intention among Centennials. Academy of Marketing Studies Journal 25(3):1-20

76. Sheeran P, Taylor S (1999) Predicting intentions to use condoms: a meta-analysis and comparison of the theories of reasoned action and planned behavior. J Appl Soc Psychol 29(8):1624-1675

77. Sheng G, Xie F, Gong S, Pan H (2019) The role of cultural values in green purchasing intention: Empirical evidence from Chinese consumers. International Journal of Consumer Studies 43(3):315326

78. Shim S, Xiao JJ, Barber BL, Lyons AC (2009) Pathways to life success: A conceptual model of financial well-being for young adults. Journal of Applied Developmental Psychology 30(6):708-723

79. Skamp K, Boyes E, Stannistreet M (2009) Global warming responses at the primary secondary interface 1. students' beliefs and willingness to act. Australian Journal of Environmental Education, 25(2009),15-30 
80. Slavoljub J, Zivkovic L, Sladjana A, Dragica G, Zorica PS (2015) To the environmental responsibility among students through developing their environmental values. Procedia-Social Behavioral Sciences 171:317-322

81. Stern MJ, Powell RB, Ardoin NM (2010) Evaluating a constructivist and culturally responsive approach to environmental education for diverse audiences. The Journal of Environmental Education 42(2):109-122

82. Stern P (2000) Toward a coherent theory of environmentally significant behavior. J Soc Issues 56(3):407-424

83. Stern PC, Dietz T (1994) The value basis of environmental concern. J Soc Issues 50(3):65-84

84. Stern PC, Dietz T, Abel T, Guagnano GA, Kalof L (1999) A value-belief-norm theory of support for social movements: The case of environmentalism. Human Ecology Review 6(2):81-97

85. Stout DT, Walsh TC, Burian SJ (2017) Ecosystem services from rainwater harvesting in India. Urban Water Journal 14(6):561-573

86. Suki NM (2016) Consumer environmental concern and green product purchase in Malaysia: structural effects of consumption values. J Clean Prod 132:204-214

87. Tommasetti A, Singer P, Troisi O, Maione G (2018) Extended theory of planned behavior (ETPB): investigating customers' perception of restaurants' sustainability by testing a structural equation model. Sustainability 10(7):1-21

88. Van der Werff E, Steg L, Keizer K (2013) It is a moral issue: The relationship between environmental self-identity, obligation-based intrinsic motivation and pro-environmental behaviour. Glob Environ Change 23(5):1258-1265

89. Vicente-Molina MA, Fernández-Sáinz A, Izagirre-Olaizola J (2013) Environmental knowledge and other variables affecting pro-environmental behaviour: comparison of university students from emerging and advanced countries. J Clean Prod 61:130-138

90. Wang S, Fan J, Zhao D, Yang S, Fu Y (2016) Predicting consumers' intention to adopt hybrid electric vehicles: using an extended version of the theory of planned behavior model. Transportation 43(1):123-143

91. Ward S (1974) Consumer socialization. J Consum Res 1(2):1-14

92. Whitmarsh L, O'Neill S (2010) Green identity, green living? The role of pro-environmental self-identity in determining consistency across diverse pro-environmental behaviours. Journal of Environmental Psychology 30(3):305-314

93. Wong $\mathrm{CH}$, Tan GWH, Tan BI, Ooi KB (2015) Mobile advertising: The changing landscape of the advertising industry. Telematics Inform 32(4):720-734

94. Wong CWY, Miao X, Cui S, Tang Y (2018) Impact of corporate environmental responsibility on operating income: Moderating role of regional disparities in China. J Bus Ethics 149(2):363-382

95. Wong TKY, Wan PS (2011) Perceptions and determinants of environmental concern: The case of Hong Kong and its implications for sustainable development. Sustain Dev 19(4):235-249 
96. Wynveen CJ, Sutton SG (2015) Engaging the public in climate change-related pro-environmental behaviors to protect coral reefs: The role of public trust in the management agency. Marine Policy 53:131-140

97. Xu X, Hua Y, Wang S, Xu G (2020) Determinants of consumer's intention to purchase authentic green furniture. Resour Conserv Recycl 156:1-8

98. Yue B, Sheng G, She S, Xu J (2020) Impact of consumer environmental responsibility on green consumption behavior in china: The role of environmental concern and price sensitivity. Sustainability, 12(5), 2074

99. Zagzebski L (2017) What is knowledge?. The Blackwell Guide to Epistemology, 92-116

100. Zhang X, Geng G, Sun P (2017) Determinants and implications of citizens' environmental complaint in China: Integrating theory of planned behavior and norm activation model. J Clean Prod 166:148156

\section{Figures}

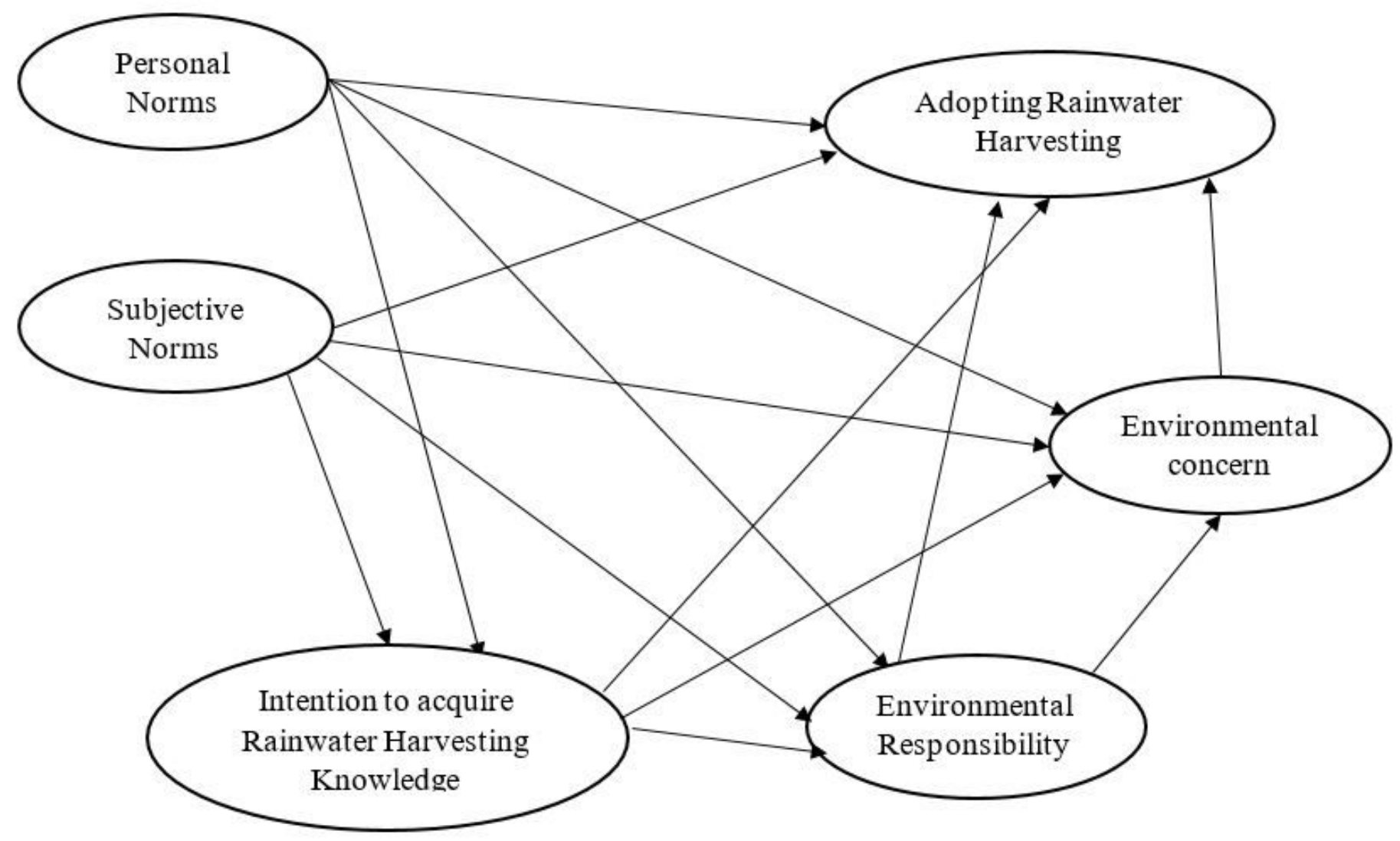

\section{Figure 1}

The Proposed hypothetical model 


\section{Supplementary Files}

This is a list of supplementary files associated with this preprint. Click to download.

- Appendix.docx 